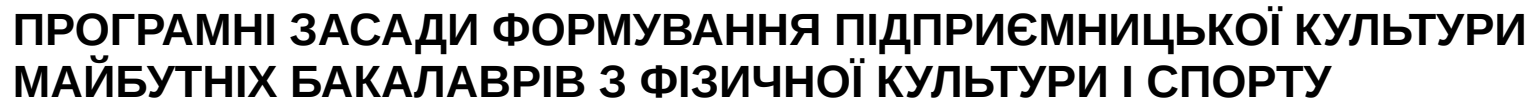

\title{
THE PROGRAM FUNDAMENTALS OF FORMATION OF ENTREPRENEURIAL CULTURE OF FUTURE BACHELORS ON PHYSICAL CULTURE AND SPORTS
}

\begin{abstract}
У статmі розглянуто змістовне наповнення освітньо-просресійних програм деяких вітчизняних закладів вищої освіти, що дозволило виявити певні недоліки, серед яких: різний розподіл годин між варіативною та нормативною частинами навчального плану, значна відмінність між назвами навчальних дисциплін з аналогічним змістом, наявність дисциплін, які мають побічне відношення до підприємницької діяльності. Метою статmі $\epsilon$ розроблення на основі конкретизованих програмних результатів навчання авторської освітньо-профресійної програми підготовки бакалаврів зі спеціальності 017 «Фізична культура іспорт», компоненти якої спрямовані на формування підприємницької культури здобувачів освіти. Як орієнтири для формулювання результатів навчання обрано компетентності, зазначені у Стандарті бакалаврської освіти зі спеціальності 017 Фізична культура і спорт, який набрав чинності у 2019 році. Визначено результати навчання, що є компліментарними підприємницькій культурі майбутніх бакалаврів. На основі визначених програмних результатів навчання обрано компоненти освітньоі програми, зміст яких спрямовано на фрормування підприємницької культури здобувачів освіти. Такими компонентами стали: окремі навчальні дисципліни; змістовні модулі визначених навчальних дисциплін; один з розділів навчальної практики на четвертому курсі. Зазначено, що підготовка майбутніх бакалаврів фрізичної культури і спорту до підприємницької діяльності обов'язково має проходити з урахуванням міжпредметних зв'язків, взаємопроникнення й логічного підпорядкування всіх визначених компонентів освітньої програми загальній меті. Для реалізації принципів і положень авторської концепції обов'язковим $є$ віднесення більшості дисциплін, зміст яких повністю або частково спрямовано на форомування підприємницької культури, до вибіркової частини освітньоі програми.

Ключові слова: освітньо-професійна програма, заклад вищої освіти, програмні результати навчання, фформування підприємницької культури, Стандарт бакалаврської освіти, авторська концепція.
\end{abstract}

The article stipulates that in accordance with the regulations governing the content of education, the targets of education of the future bachelor of physical culture and sports in general, and guidelines for their preparation for entrepreneurship, in particular, must be expressed in the form of competencies and learning outcomes. Having considered the content of educational and professional programs of some higher educational institutions, it has been revealed that there are certain shortcomings, including: different distribution of hours between the variable and normative parts of the curriculum, a significant difference between the names of disciplines with similar content, and a number of disciplineswhich are not directly related to entrepreneurial activity. The purpose of the article is to develop the author's educational and professional training program for bachelors of the specialty 017 "Physical Culture and Sports", which is based on specific program learning outcomesand whose components are aimed at forming the entrepreneurial culture of students. The competencies specified in the Bachelor's Education Standard of the specialty 017 Physical Culture and Sports, which came into force in 2019, were chosen as guidelines for formulating learning outcomes. The learning outcomes that are complementary to the entrepreneurial culture of future bachelors are determined. Based on the defined program learning outcomes, the components of the educational program which content is aimed at forming the entrepreneurial culture of students have been selected. These components are: individual disciplines; meaningful modules of certain academic disciplines; one of the sections of educational practice in the fourth year. It is noted that the preparation of future bachelors of physical culture and sports for entrepreneurial activity must take into account the interdisciplinary links, interpenetration and logical subordination of all identified components of the educational program to the common goal. To implement the principles and provisions of the author's concept, it is necessary to include most of the disciplines, the content of which is fully or partially aimed at forming an entrepreneurial culture, in the optional part of the educational program.

Key words: educational-professional program, institution of higher education, program learning outcomes, formation of entrepreneurial culture, Standard of bachelor's education, author's concept.
Постановка проблеми. Відповідно до нормативних документів, які регламентують зміст освіти, цільові орієнтири освіти майбутнього бакалавра фрізичної культури і спорту загалом і орієнтири його підготовки до підприємницької діяльності зокрема обов'язково мають бути виражені у формі компетентностей і програмних результатів навчання. Компетентнісний підхід передбачає відображення у системному і цілісному вигляді образу результату освіти, а також представлення цього результату як ознак готовності здобувача освіти застосувати відповідні знання, уміння та досвід на практиці.

Аналіз останніх досліджень і публікацій. Питання розробки освітніх програм у контексті нових стандартів вищої освіти розглядали такі автори, як Ю. Рашкевич [9], М. Буренко [1] та інші. Аналіз освітньо-професійних програм (ОПП) зі спеціальності 017 «Фізична культура і спорт» [3-7] показав, що їх розробниками вимоги Стандарту реалізуються по-різному, що виражається у різних 
шляхах формування нормативних компетентностей і досягнення очікуваних результатів освітнього процесу. Звертає також на себе увагу дещо різний розподіл годин між варіативною та нормативною частинами навчального плану, а також значна відмінність між назвами навчальних дисциплін, зміст яких, по суті, $€$ аналогічним.

Виділення не вирішених раніше частин загальної проблеми. ОПП спеціальності 017 «Фізична культура і спорт» традиційно містять дисципліни, які стосуються підприємницької діяльності побічно, що створює потребу в розробці таких концептуальних засад фрормування змісту освітньої професійної програми, які можуть стати основою внутрішньо узгодженої системи впливів, спрямованих на фрормування підприємницької культури у майбутніх бакалаврів з фрізичної культури та спорту.

Постановка завдання. Метою статті $€$ розроблення на основі конкретизованих програмних результатів навчання авторської освітньо-професійної програми підготовки бакалаврів зі спеціальності 017 «Фізична культура і спорт», компоненти якої спрямовані на фрормування підприємницької культури здобувачів освіти.

Виклад основного матеріалу дослідження. Компетентісний підхід є особливо актуальним під час підготовки здобувачів освіти до підприємницької діяльності. Так, у доповіді міжнародної комісії ЮНЕСКО з освіти зазначалося, що підприємцям потрібна не кваліфікація, яка часто асоціюється 3 умінням здійснювати ті чи інші матеріальні дії, а компетентність як своєрідний коктейль навичок, у якому поєднуються кваліфрікація у чіткому сенсі цього слова, а також соціальна поведінка, ініціативність та здатність працювати в групі [2].

Виконуючи означене завдання передусім приступимо до уточнення цільових компетентностей студентів спеціальності 017 «Фізична культура і спорт», співвіднесених з їхньою підприємницькою культурою, розуміючи під компетентностями динамічну комбінацію знань, умінь, навичок, способів мислення, поглядів, цінностей, особистих якостей, що визначає здатність особи успішно соціалізуватися, провадити професійну та навчальну діяльність [8].

Першим кроком на обраному шляху став аналіз стандарту бакалаврської освіти за спеціальністю 017 Фізична культура і спорт (далі - Стандарт), який набрав чинності у 2019 році.

Як бачимо з цього документу, предметна сорера підготовки майбутніх бакалаврів фрізичної культури і спорту окреслюється таким чином:

- об'єкти вивчення та діяльності - сфрера фрізичної культури і спорту;

- цілі навчання, сорормульовані у фрормі інтегральної компетентності, яка спирається на НPК, підготовка фрахівців, здатних розв'язувати складні спеціалізовані завдання та практичні проблеми, що характеризується комплексністю та невизначеністю умов під час профресійної діяльності у сфрері фрізичної культури і спорту або у процесі навчання;

- теоретичний зміст предметної сфрери - парадигми, концепції, теорії фрізичної культури і спорту; соціально-гуманітарні науки; педагогіка і психологія; основи анатомії, фрізіології, біохімії, гігієни, спортивної медицини; загальна теорія здоров'я, здорового способу життя;

- методи, методики та технології - загальнонаукові методи пізнання та дослідницької діяльності; спостереження, опитування, тестування та вимірювання у фрізичній культурі і спорті; словесні, наочні та практичні методи фрізичного виховання та спортивної підготовки; технології організації та проведення спортивно-оздоровчих та спортивних заходів; надання долікарської допомоги; інформаційно-комунікаційні технології;

- інструменти та обладнання: сучасне інфрормаційно-комунікативне обладнання; спеціалізоване програмне забезпечення; фрізкультурно-спортивне спорядження та обладнання [10]

Орієнтири освітнього процесу у цьому Стандарті визначені у формі компетентностей, згрупованих у такі кластери: інтегральна компетентність; загальні компетентності; спеціальні (фахові) кометентності [10].

Вважаємо, що у контексті фрормування підприємницької культури у майбутніх бакалаврів фрізичної культури і спорту усі загальні компетентності, наведені у Стандарті, мають безпосереднє відношення до фрормування цієї професійної якості. Адже складно представити успішного підприємця у галузі фрізичної культури та спорту, не здатного реалізовувати свої громадянські права і обов'язки на користь сталого розвитку суспільства; не здатного працювати у команді; з відсутністю навичок самоменеджменту; не спроможного використовувати інформаційні технології; 3 низьким рівнем комунікаційних умінь; відірваного від практики тощо [10].

щодо спеціальних фахових компетентностей, на наш погляд, вони теж віддзеркалюють різні аспекти підприємницької культури, оскільки і використання спортивних споруд, спеціального обладнання та інвентарю, і застосовування сучасних технологій управління суб'єктами сорери фрізичної культури і спорту, і безперервний професійний розвиток, а також інші компетентності, визначені у Стандарті, $€$ ринковими інструментами, що дозволяють реалізувати підприємницький потенціал фрахівця галузі фрізичної культури і спорту у ринкових умовах.

Отже, вважаємо, що і загальні, і спеціальні компетентності, наведені у Стандарті, виступають своєрідним підґрунтям для набуття та реалізації підприємницької культури, срундаментом, на якому будуватиметься підприємницький менталітет [10]. 
Компетентності Стандарту виступають орієнтиром для форомуювання результатів навчання очікуваних й доступних вимірюванню конкретних досягнень здобувачів освіти, що відображають те, як вони здатні виконувати професійні фрункції після завершення освітньої програми або її частини [8].

Подальший аналіз Стандарту спрямовувався на визначення результатів навчання, компліментарних підприємницькій культурі майбутніх бакалаврів спеціальності 017 «Фізична культура і спорт». Зокрема, серед наведених у Стандарті результатів навчання наша увага зосередилася на таких:

- здійснювати аналіз суспільних процесів у ссрері фрізичної культури і спорту, демонструвати власне бачення шляхів розв'язання наявних проблем;

- уміти обробляти дані з використанням сучасних інфрормаційних та комунікаційних технологій;

- показувати навички самостійної роботи, демонструвати критичне та самокритичне мислення;

- засвоювати нову фрахову інфрормацію, оцінювати й представляти власний досвід, аналізувати й застосовувати досвід колег;

- аналізувати процеси становлення та розвитку різних напрямів спорту, олімпійського руху та олімпійської освіти на міжнародному та національному рівнях;

- аргументувати управлінські рішення для вирішення проблем, які виникають в роботі суб'єктів фрізичної культури і спорту; мати навички лідерства;

- використовувати нормативні та правові акти, що регламентують професійну діяльність;

- застосовувати набуті теоретичні знання для розв'язання практичних завдань та змістовно інтерпретувати отримані результати [8].

Звертаємо увагу на те, що ці та інші очікувані результати навчання можуть бути розвинені на наступному (магістерському) освітньому рівні.

Зіставлення ОПП деяких вітчизняних закладів вищої освіти 3 погляду наявності в них структурних компонентів (дисциплін і навчальних практик), спрямованих на соормування підприємницької культури, показало, що в деяких 3 них є дисципліни, зміст яких безпосередньо спрямований на формування компетентностей, асоційованих із цією професійною якістю.

Так, наприклад, ОПП Відкритого міжнародного університету розвитку людини «Україна» включає дисципліну «Комерціалізація стартап-проєктів», зміст якої, очевидно, відтворює специфріку підприємницької діяльності [3]. Однак такі дисципліни присутні далеко не у всіх закладах вищої освіти (3ВО), які проводять підготовку майбутніх бакалаврів фрізичної культури і спорту.
Більш традиційною в ОПП спеціальності 017 «Фізична культура і спорт» виглядає присутність дисциплін, які стосуються підприємницької діяльності побічно. Наприклад, це такі дисципліни, як «Економічна теорія»; «Основи менеджменту та маркетингу у фрізичній культурі та спорті»; «Спортивні споруди та обладнання»; «Сучасні фрітнестехнології»; «Управління у фрізичній культурі та спорті»; «Технічні засоби у фрізичному вихованні та спорті»; «Оздоровчий фрітнес» та інші [3; 5].

Логічно припустити, що зміст цих дисциплін також передбачає формування компетентностей, необхідних для інноваційної діяльності у галузі фрізичної культури і спорту.

Відзначимо також, що у проаналізованих ОПП [3; 4; 5; 6; 7] більшість дисциплін, зміст яких перетинається із формуванням підприємницької культури, належить до вибіркових компонентів. При цьому ці дисципліни можуть належати як до циклу професійної, так і до циклу загальної підготовки. Осторонь стоїть дисципліна «Інсрормаційні технології в галузі», яка присутня у всіх проаналізованих програмах і належить до обов'язкових компонентів циклу профресійної підготовки [3; 4; 5].

щодо навчальних практик відзначимо, що всі проаналізовані ОПП мають достатню кількість годин практичної підготовки для того, щоб можна було частину їх змісту спрямувати на залучення студентів до підприємницької або комерційної діяльності.

Загалом вважаємо, що різноманітність форм реалізації змісту Стандарту в ОПП різних ЗВО сприяє підвищенню конкуренції на ринку освітніх послуг і сприяє підвищенню якості фрізкультурноспортивної освіти.

Під час розробки авторської ОПП, спрямованої на формування підприємницької культури майбутніх бакалаврів фрізичної культури і спорту, було враховано досвід закладів вищої освіти нашої країни. При цьому, маючи обмеження з боку чинного Стандарту, ми мали певну свободу у розробці компонентів освітньої програми. Зокрема, на основі визначених вище програмних результатів навчання ми визначили компоненти освітньої програми, зміст яких має бути спрямований на фрормування підприємницької культури здобувачів освіти. Такими компонентами стали: окремі навчальні дисципліни; змістовні модулі визначених навчальних дисциплін; один з розділів навчальної практики на четвертому курсі.

Співвідношення очікуваних результатів навчання, асоційованих із формуванням підприємницької культури, із компонентами розробленої ОПП представлено у табл. 1.

Важливим $\epsilon$ те, що підготовка майбутніх бакалаврів фрізичної культури і спорту до підприємницької діяльності обов'язково має проходити 3 урахуванням міжпредметних зв'язків, взаємопро- 
Забезпечення програмних результатів навчання компонентами освітньої програми

Таблиця 1

\begin{tabular}{|c|c|c|c|c|c|c|c|c|}
\hline \multirow{2}{*}{ Компоненти освітньо-профресійної програми } & \multicolumn{8}{|c|}{ Програмні результати навчання* } \\
\hline & 1 & 2 & 3 & 4 & 5 & 6 & 7 & 8 \\
\hline $\begin{array}{l}\text { Змістовий модуль «Цифрове забезпечення підприємництва» дис- } \\
\text { ципліни «Інформаційні технології у фрізичній культурі і спорті » (2-й } \\
\text { семестр) }\end{array}$ & & + & & & & & & \\
\hline $\begin{array}{l}\text { Змістовий модуль «Загальні положення та особливості маркетингу } \\
\text { галузі фрізичної культури і спорту» дисципліни «Маркетинг фрізичної } \\
\text { культури і спорту» (2-й семестр) }\end{array}$ & & & + & & + & & & \\
\hline $\begin{array}{l}\text { Змістовий модуль «Визначення нестатків і потреб споживачів послуг } \\
\text { галузі фрізичної культури і спорту» дисципліни «Маркетинг фрізичної } \\
\text { культури і спорту» (2-й семестр) }\end{array}$ & + & & & & + & & & \\
\hline $\begin{array}{l}\text { Змістовий модуль «Розробка спортивно-оздоровчих послуг» дисци- } \\
\text { пліни «Маркетинг орізичної культури і спорту» (2-й семестр) }\end{array}$ & & & & & + & & & \\
\hline $\begin{array}{l}\text { Змістовий модуль «Просування послуг у спортивно-оздоровчій галузі» } \\
\text { дисципліни «Маркетинг фрізичної культури і спорту» (2-й семестр) }\end{array}$ & & & & & + & & & \\
\hline $\begin{array}{l}\text { Змістовий модуль «Сутність і принципи спортивного менеджменту» } \\
\text { дисципліни «Менеджмент у фрізичній культурі і спорті» (2-й семестр) }\end{array}$ & & & & & & + & + & \\
\hline $\begin{array}{l}\text { Змістовий модуль «Управлінський цикл» дисципліни «Менеджмент у } \\
\text { фрізичній культурі і спорті» (2-й семестр) }\end{array}$ & & & & & & + & & \\
\hline $\begin{array}{l}\text { Змістовий модуль «Технологія прийняття рішень» дисципліни } \\
\text { «Менеджмент у фрізичній культурі і спорті» (2-й семестр) }\end{array}$ & & & & & & + & & \\
\hline $\begin{array}{l}\text { Змістовий модуль «Засади самоменеджменту» дисципліни «Менедж- } \\
\text { мент у фрізичній культурі і спорті» (2-й семестр) }\end{array}$ & & & & & & + & + & \\
\hline $\begin{array}{l}\text { Змістовий модуль «Стартапи у галузі» дисципліни «Інноваційні техно- } \\
\text { логії спортивного тренування та фрізичної культури» (5-й семестр) }\end{array}$ & & & & + & + & & & + \\
\hline $\begin{array}{l}\text { Змістовий модуль «Методики креативного мислення» дисципліни } \\
\text { «Підприємництво у фрізичній культурі і спорті» (6-й семестр) }\end{array}$ & & & & + & + & & & + \\
\hline $\begin{array}{l}\text { Змістовий модуль «Сутність підприємницької діяльності» дисципліни } \\
\text { «Підприємництво у фрізичній культурі і спорті» (6-й семестр) }\end{array}$ & & & & + & + & + & & + \\
\hline $\begin{array}{l}\text { Змістовий модуль «Організаційно-правові форми підприємницької } \\
\text { діяльності» дисципліни «Підприємництво у фрізичній культурі і спорті» } \\
\text { (6-й семестр) }\end{array}$ & & & & & & + & + & \\
\hline $\begin{array}{l}\text { Змістовий модуль «Основи підприємницької культури» дисципліни } \\
\text { «Підприємництво у фрізичній культурі і спорті» (6-й семестр) }\end{array}$ & + & & + & + & + & & & + \\
\hline Курсова робота з фраху (7-й семестр) & + & + & + & + & + & & & + \\
\hline $\begin{array}{l}\text { Виробнича практика (Спілкування у бізнес-середовищі як помічника } \\
\text { менеджера у закладах спортивно-оздоровчої галузі) (8-й семестр) }\end{array}$ & & & + & & & + & + & + \\
\hline
\end{tabular}

*Результати навчання: 1. Здійснювати аналіз суспільних процесів у сфері фрізичної культури і спорту, демонструвати власне бачення шляхів розв'язання наявних проблем. 2. Уміти обробляти дані з використанням сучасних інформаційних та комунікаційних технологій. 3. Показувати навички самостійної роботи, демонструвати критичне та самокритичне мислення. 4 Засвоювати нову фахову інформацію, оцінювати й представляти власний досвід, аналізувати й застосовувати досвід колег. 5. Аналізувати процеси становлення та розвитку різних напрямів спорту, олімпійського руху та олімпійської освіти на міжнародному та національному рівнях. 6. Аргументувати управлінські рішення для вирішення проблем, які виникають в роботі суб'єктів фрізичної культури і спорту; мати навички лідерства. 7. Використовувати нормативні та правові акти, що регламентують професійну діяльність. 8. Застосовувати набуті теоретичні знання для розв'язання практичних завдань та змістовно інтерпретувати отримані результати

никнення й логічного підпорядкування всіх визначених компонентів освітньої програми загальній меті. Зазначимо також, що за нашим задумом для реалізації принципів і положень авторської концепції обов'язковим $€$ віднесення більшості дисциплін, зміст яких повністю або частково спрямовано на формування підприємницької культури, до вибіркової частини освітньої програми.

Висновки із цього дослідження і подальші перспективи в цьому напряму. На основі конкретизованих програмних результатів навчання розроблено авторську ОПП, компоненти якої спрямовані на формування підприємницької культури здобувачів освіти. Такими компонентами є: окремі навчальні дисципліни; змістові модулі визначених навчальних дисциплін; один з розділів навчальної практики на 4-му курсі. Отже, обґрунтовані концептуальні засади розробки освітньої професійної програми зі спеціальності 017 «Фізична культура і спорт» можна розглядати як основу внутрішньо узгодженої системи впливів, спрямованих на формування підприємницької культури у майбутніх бакалаврів 3 фрізичної культури та спорту. Перспективами подальших наукових пошуків у цьому напряму можуть бути результати перевірки зазначеного вище припущення. 


\section{БІБЛІОГРАФІЧНИЙ СПИСОК:}

1. Буренко М.С. Формування фаховий компетенцій майбутніх тренерів-викладачів у процесі вивчення циклу професійно-орієнтованих дисциплін : дис. ... канд. пед. наук: 13.00.04. Запоріжжя, 2012. 224 с.

2. Доклад международной комиссии по образованию, представленный ЮНЕСКО «Образование: сокрытое сокровище». Москва : ЮНЕСКО, 1997. 31 с.

3. Освітньо-профресійна програма «Фізична культура і спорт» першого (бакалаврського) рівня вищої освіти. Галузь знань - 01 Освіта / Педагогіка, спеціальність 017 Фізична культура і спорт. Київ: Відкритий міжнародний університет розвитку людини «Україна», 2019. 21 с.

4. Освітньо-просресійна програма «Фізична культура і спорт» першого (бакалаврського) рівня вищої освіти. Галузь знань - 01 Освіта / Педагогіка, спеціальність - 017 Фізична культура і спорт. Херсон : Херсонський державний університет, 2019. 22 с.

5. Освітньо-просесійна програма «Фізична культура і спорт» першого (бакалаврського) рівня вищої освіти. Галузь знань - 01 Освіта/Педагогіка, спеціальність - 017 Фізична культура і спорт. Дніпро : Придніпровська державна академія фрізичної культури і спорту, 2018. 27 c.

6. Освітньо-професійна програма «Фізична культура і спорт» першого (бакалаврського) рівня вищої освіти. Галузь знань - 01 Освіта / Педагогіка, спеціальність - 017 Фізична культура і спорт. Тернопіль: Тернопільський національний педагогічний універсиет імені Володимира Гнатюка, 2017. 19 с.

7. Освітньо-професійна програма «Фізичне виховання» здобуття першого (бакалаврського) рівня вищої освіти. Галузь знань - 01 Освіта / Педагогіка, спеціальність - 017 Фізична культура і спорт. Запоріжжя : НУ«Запорізька політехніка», 2019. 11 с.

8. Про освіту: Закон України № 2145-VIII від 05.09.2017 p. URL: http://zakon0.rada.gov.ua/laws/ show/2145-19/print.

9. Рашкевич Ю.М. Методичні рекомендації щодо опису освітньої програми в контексті нових стандартів вищої освіти. 66 с. URL: https://erasmusplus.org. ua/korysna-informatsiia/korysni-materialy/category/3materialy-natsionalnoi-komandy-ekspertiv-shchodozaprovadzhennia-instrumentiv-bolonskoho-protsesu. html? download=285: metodychni-rekomendatsiishchodo-opysu-osvitnoi-prohramy-v-konteksti-novykhstandartiv-vyshchoi-osvity.

10. Стандарт вищої освіти України перший (бакалаврський) рівень, галузь знань 01 «Освіта / Педагогіка», спеціальність 017 «Фізична культура і спорт». Затверджено і введено в дію наказом МОН України № 567 від 24.04.2019 р. 12 с. 